\title{
Role of Breast Surgery in BRCA Mutation Carriers
}

\author{
Carolin Nestle-Krämling ${ }^{\mathrm{a}}$ Thorsten Kühn ${ }^{\mathrm{b}}$ \\ aDepartment of Senology, Sana Krankenhaus Düsseldorf-Gerresheim, \\ ${ }^{\mathrm{b}}$ Klinik für Frauenheilkunde und Geburtshilfe, Klinikum Esslingen, Germany
}

\section{Keywords}

BRCA mutation carrier - Mastectomy techniques . Reconstructive surgery of the breast - Prophylactic mastectomy

\section{Summary}

BRCA mutation carriers have a life-long breast cancer risk between 55 and $85 \%$ and a high risk of developing breast cancer at a very young age, depending on the type of mutation. The risk of developing contralateral breast cancer after a first breast cancer is elevated up to $65 \%$, especially in case of BRCA 1 mutation and young age at the first breast cancer. Since bilateral prophylactic mastectomy is associated with a risk reduction of 90$95 \%$ of developing primary or contralateral breast cancer, this option is a key point within the counseling process for patient information and shared decision-making of mutation carriers. Although the local control after breast-conserving therapy in mutation carriers seems to be comparable to that of sporadic breast cancer patients, individual patient information and counseling should include all alternative procedures of oncologically adequate mastectomy techniques and immediate reconstruction. Excellent cosmetic results, high levels of life quality, and good patient acceptance can be achieved with the recent developments in reconstructive surgery of the breast.

\section{Introduction}

Beside the life-long breast cancer risk of 55-85\%, BRCA mutation carriers have a mutation-dependent high risk of developing breast cancer at a very young age [1]. Therefore, the role of breast surgery in BRCA mutation carriers comprises bilateral prophylactic mastectomy with various techniques of immediate breast reconstruction in healthy carriers and in breast cancer patients, as well as the whole spectrum of oncologic breast surgery within the concept of systemic and

\author{
Schlüsselwörter \\ BRCA-Mutationsträgerin - Mastektomietechniken · \\ Rekonstruktive Brustchirurgie - Prophylaktische \\ Mastektomie
}

\section{Zusammenfassung}

BRCA-Mutationsträgerinnen haben ein lebenslanges Brustkrebsrisiko von 55-85\% und je nach Art der Mutation eine hohe Wahrscheinlichkeit in einem sehr jungen Alter zu erkranken. Das Risiko eines kontralateralen Mammakarzinoms nach einer ersten Brustkrebserkrankung beträgt bis zu 65\%, insbesondere bei jungem Ersterkrankungsalter. Da eine bilaterale prophylaktische Mastektomie mit einer Risikoreduktion um 90-95\% für die Entwicklung eines primären oder auch kontralateralen Mammakarzinoms einhergeht, ist diese Option ein zentrales Thema im Beratungsablauf zur Patientinnenaufklärung und Entscheidungsfindung von Mutationsträgerinnen. Auch wenn die lokale Kontrolle nach brusterhaltender Therapie bei Mutationsträgerinnen derjenigen bei Frauen mit sporadischem Mammakarzinom vergleichbar ist, sollte die individuelle Patientinneninformation und Beratung alle Alternativen einer onkologisch adäquaten Mastektomietechnik mit Sofortrekonstruktion der Brust umfassen. Unter Einsatz der modernen Entwicklungen in der rekonstruktiven Brustchirurgie sind damit hervorragende ästhetische Ergebnisse bei hoher Lebensqualität sowie eine gute Patientinnenakzeptanz zu erzielen.

locoregional breast cancer therapy. Breast surgery in mutation carriers is always associated with intensive individual counseling and individualized decision making. Frequently, the information of being a BRCA mutation carrier is not available at the time of breast cancer surgery and the breast cancer therapy concept has to be planned considering a possible positive result. Several aspects of breast surgery in mutation carriers seem contradictory to physicians and patients and should be discussed.

\section{KARGER \\ Fax +497614520714 \\ Information@Karger.de}

www.karger.com (c) 2012 S. Karger GmbH, Freiburg

661-3791/12/0075-0378\$3800

Accessible online at:

www.karger.com/brc 


\section{Decision for and Frequency of Prophylactic Mastectomy}

In terms of prevention, prophylactic mastectomy is the most effective way to prevent BRCA mutation carriers from developing primary or contralateral breast cancer, with a $90-95 \%$ risk reduction compared to the alternative option of intensified surveillance $[2,3]$. But depending on country culture and the trends in counseling, the majority of healthy mutation carriers decide against bilateral prophylactic mastectomy. In fact, it is a very individualized decision.

Several publications and the last Cochrane review on prophylactic mastectomy for the prevention of breast cancer published in 2010 report on the potential and the amount of risk reduction as breast cancer incidence, all-cause and breast cancer mortality, physical morbidity, and quality of life after prophylactic mastectomy. Altogether 38 publications with more than 7,380 women were evaluated and demonstrated that prophylactic mastectomy was effective in terms of reduction of breast cancer-specific mortality, reduction of breast cancer incidence, and life quality after surgery. Physical morbidity after prophylactic surgery revealed a complication rate of $20-50 \%$, and data on overall survival of all causes was contradictory [4]. Esthetic outcome and life quality revealed even stable good results in terms of long-term satisfaction, with $90 \%$ of the patients being satisfied and willing to choose the procedure again even 20 years after prophylactic surgery $[5,6]$.

In a recent large international survey study on preventive practices in 9 countries, 2,677 women completed a questionnaire 4 years after genetic testing, and depending on country of residence, there was a low overall rate of prophylactic mastectomy of $18 \%$ and a large difference in the uptake of prophylactic mastectomy. The highest rates of prophylactic mastectomy were seen in the USA (36.3\%) and The Netherlands $(32.7 \%)$, the lowest rates in Israel $(4.2 \%)$ and Poland (2.7\%) [7]. The highest uptake of prophylactic mastectomy was reported of unaffected Danish women with a 10-year uptake of 50\% [8]. Predictive factors for the women's decisions for prophylactic bilateral mastectomy in several studies are young age and a strong family history as well as an own history of breast cancer and the type of surgery for the first cancer for contralateral prophylactic mastectomy $[9,10]$. Again in contralateral prophylactic mastectomy, the uptake rates vary significantly between countries, with an overall rate of $27 \%$, which is higher than in unaffected women; the lowest rate is reported from Norway $(0 \%)$ and the highest one of up to $50 \%$ from the USA [9].

\section{Breast Cancer Surgery in Mutation Carriers - Timing and Technique?}

In terms of local control, breast-conserving therapy in the treatment of primary breast cancer of mutation carriers seems as effective as in sporadic breast cancer patients [11] or at most slightly elevated in a longer follow-up period of more than 10 years $[12,13]$. But the optimal surgical procedure in affected BRCA mutation carriers remains controversial and individual. Bilateral and contralateral prophylactic mastectomy at the time of diagnosis should be discussed especially with young patients because of their high probability of contralateral breast cancer [14] and an associated possible survival benefit [15]. In fact, the decision is highly individual and has to be made with regard to oncological aspects such as tumor stage and tumor therapy, but also respecting the patient's wish. Within this context, it is repeatedly seen that patients even with advanced breast cancer seek for bilateral mastectomy and reconstruction to exclude the problem of local recurrence. In this situation, care should be taken that the timing of essential oncological therapies including chemotherapy and, whenever indicated, radiation therapy is placed upfront to complex prophylactic and reconstructive surgery, to avoid a possibly deleterious delay of therapy. In case of indicated chemotherapy, neoadjuvant application should be the preferred option due to several advantages. Neoadjuvant chemotherapy offers the possibility to control the tumor response since there is evidence that the chemosensitivity of BRCA-associated breast cancer could differ from that of sporadic breast cancer [16]. Platinum-based chemotherapy should be discussed as a neoadjuvant chemotherapy regimen, at least when a standard anthracyclin- or taxane-based regimen has been unsuccessful. Another advantage of delaying surgery with neoadjuvant chemotherapy is the additional time frame to discuss and plan the individual options of breast-conserving or ablative and reconstructive breast cancer surgery.

\section{Mastectomy Techniques for Prophylactic Surgery - What Is Oncologically Safe?}

If mutation carriers decide for prophylactic mastectomy, it is essential to offer them options of best surgical practice under oncological and reconstructive aspects, with the aim of optimal risk reduction and at the same time with an esthetically optimal result with high scores of life quality. Skin- and nipple-sparing mastectomy techniques with various esthetic incisions (Fig. 1) are widely accepted as oncologically safe and

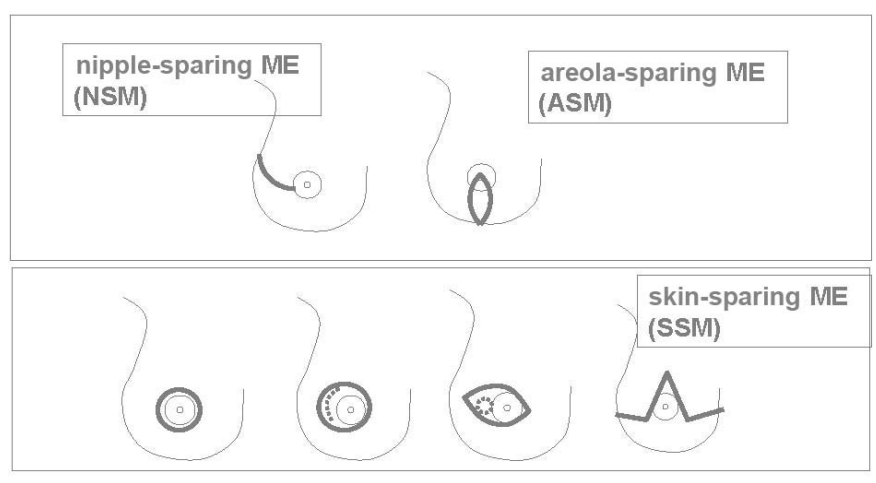

Fig. 1. Skin incision patterns of skin- and nipple-sparing mastectomy (ME). 
associated with optimal cosmetic results. Due to data on oncologic safety from more than 2,845 patients [17-19] with a recurrence rate within the nipple-areola complex (NAC) of $0.9-2 \%$ and an overall local recurrence rate of $1.3 \%$ (followup of 41 months) up to $20.8 \%$ (follow-up of 156 months), nipple-sparing mastectomy has recently been judged as a safe procedure for prophylactic and selected therapeutic mastectomy indications [20]. But it should be underlined that a proper technique is required, with every effort to resect all visible breast tissue also behind the papilla and the areola. Preoperative accurate breast imaging, including mammography, breast ultrasound and magnetic resonance imaging (MRI), should enable the surgeon to localize the individual distribution of breast tissue and to anticipate the thickness of subcutaneous fat tissue that can be left safely to ensure blood perfusion of mastectomy flaps. In case of a retroareolar tumor cell finding in the definite histopathological report, the patient has to be counseled to have the NAC removed during a second surgery. But still more and prospective data should be acquired, and the American Society of Breast Surgeons has established a nipple-sparing mastectomy (NSM) registry in order to prospectively collect data on different parameters including oncologic safety [21]. Women carrying a BRCA mutation should be counseled about all individual appropriate surgical options and the corresponding expected amount of risk reduction between 95 and $98 \%$.

Fig. 2. (a-d) Technique of bilateral areolasparing mastectomy in a ptotic breast with resection of the nipple and lower part of the areola and immediate direct to implant reconstruction. The lower implant pole is covered with a dermis flap and titanized polypropylene mesh (Tiloop $\mathrm{Bra}^{\circledR}$ ) laterally. The nipple is also immediately reconstructed by dermis flaps of residual areolar skin.

Fig. 3. (a-e) Bilateral nipple-sparing mastectomy by inframammary approach and immediate direct to implant reconstruction. The lower implant pole is covered with a porcine acellular dermis $\left(\right.$ Strattice $\left.^{\circledR}\right)$ to enhance the thin subcutaneous tissue.
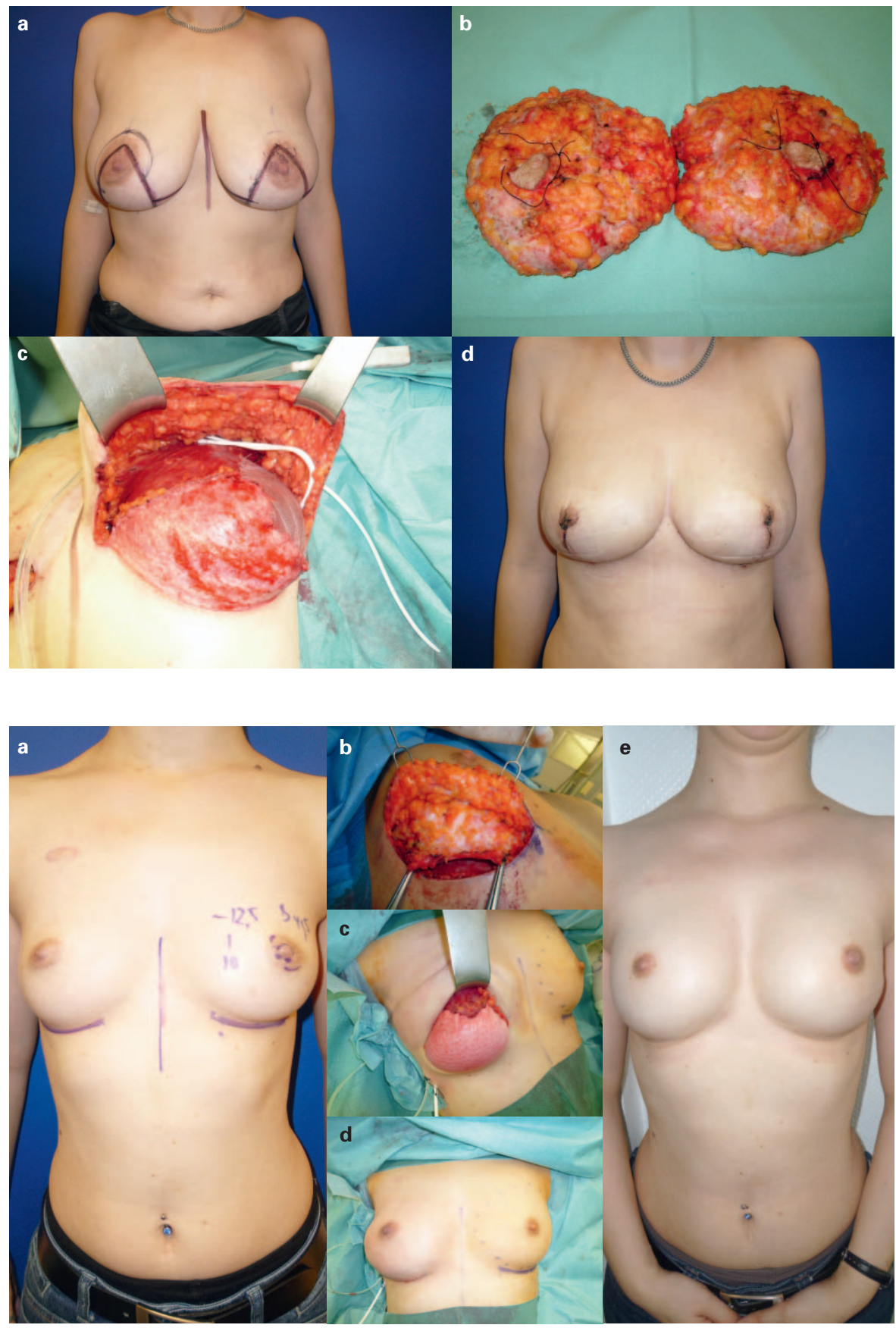


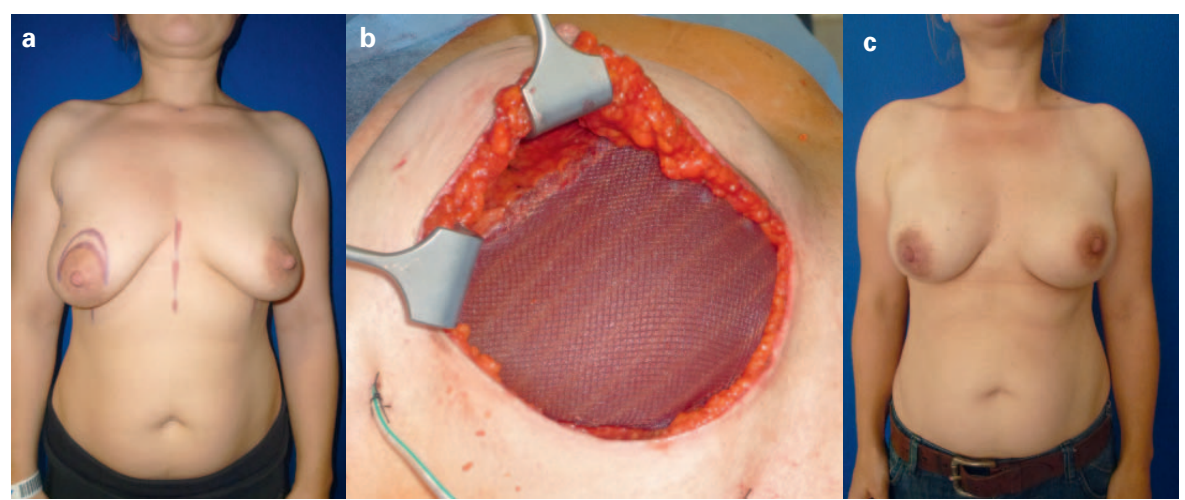

Fig. 4. (a-c) Bilateral nipple-sparing mastectomy by inframammary approach and immediate direct to implant reconstruction. The implant is stabilized and covered on the lower implant pole by a partially resorbable mesh (Seragyn $\left.\mathrm{Bra}^{\circledR}\right)$.

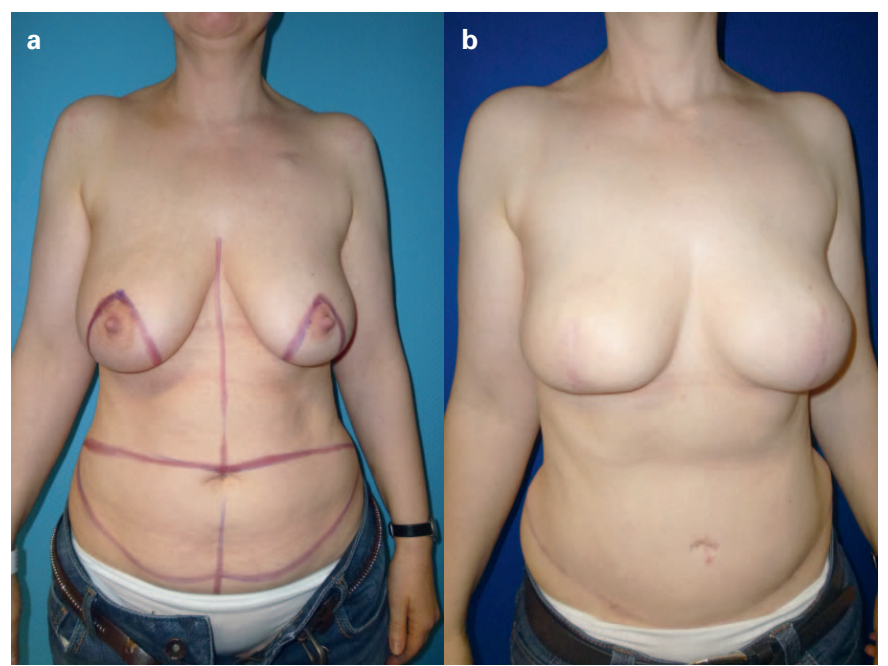

Fig. 5. (a, b) Patient with BRCA mutation and breast cancer on the right side after chemotherapy, preoperative radiation therapy, and consecutive bilateral skin-sparing mastectomy with vertical incision and split-TRAM (patient's decision).

\section{Best Choice for Bilateral Breast Reconstruction}

There is evidence that autologous reconstructive breast surgery is associated with a more stable and esthetic result than implant-based breast reconstruction. But the majority of mutation carriers $[22,23]$ and also patients with sporadic breast cancer decide for implant-based immediate reconstruction [24]. This is accompanied by a recent fast development of new materials and techniques to improve long-lasting esthetic results in implant-based and mesh- or acellular dermal matrix (ADM)-supported breast reconstruction. Although there is still a lack of high evidence concerning the long-term safety, life quality, and best material or technique, there is a whole range of new materials such as titanized polypropylene mesh (Tiloop $\mathrm{Bra}^{\circledR}$ ) [25] and partially resorbable mesh $\left(\right.$ SeragynBra $\left.{ }^{\circledR}\right)$, as well as acellular dermal matrices (ADM) of porcine $\left(\right.$ Strattice $\left.^{\circledR}\right)$, fetal bovine $\left(\right.$ Surgimend $\left.^{\circledR}\right)$, bovine pericardial $\left(\right.$ Veritas $\left.^{\circledR}\right)$ or human $\left(\right.$ Alloderm $^{\circledast}$, Epiflex $^{\circledast}$ ) $[26,27]$ origin (figs. 2-4). Further studies with mesh- or ADMsupported implant reconstruction are on the way and will add evidence to the last 5 years of experience with this technique in Germany.

For autologous reconstruction, the myocutaneous transverse rectus abdominis myocutaneous (TRAM) flap (fig. 5) is a reliable standard technique, especially for cases with unilateral autologous reconstruction, e.g. in case of unilateral implant failure due to capsular contracture after radiation [28, 29]. In cases of bilateral prophylactic mastectomy and the patient's wish to have an autologous reconstruction, the microsurgical technique of double deep inferior epigastric artery perforator (DIEP) reconstruction is the preferable standard technique [29-32], unless there is not enough volume in the lower abdomen. In this case or in case of other contraindications for DIEP or TRAM reconstruction, alternatively sequential procedures of bilateral perforator flaps from the superior or inferior gluteal artery region [33] and a bilateral free gracilis flap are individual options.

\section{Subspecialization for Bilateral Prophylactic Mastectomy and Immediate Reconstruction?}

The procedure of an oncologically safe bilateral prophylactic nipple-sparing mastectomy with an immediate mesh- or ADM-based implant reconstruction or with a microsurgical autologous breast reconstruction by double DIEP flap or sequential superior/inferior gluteal artery perforator (S-/IGAP) flap is a complex and highly demanding surgical procedure. To date, there is no apparent subspecialization of breast surgeons for mutation carriers in their search for best surgical supply. Working groups and surgical societies are called upon to take care of advanced training and information of their members about new developments in terms of optimal surgical prophylaxis and treatment of mutation carriers. In Germany, societies and working groups aim for a transparency of quality in breast surgery as a step to solve this problem. Examples are the recent introduction of a certified 'breast reconstruction center' by the German Society of Esthetic and Plastic Surgery (DGPRÄC) and, as early as in 2005, the initiation of a certified 'specialized breast surgeon' by the Working Group of Esthetic, Plastic and Reconstructive Surgery in Gynecology 
(AWO-gyn) [34]. For the group of women with hereditary breast cancer risk, the BRCA network is counseling other affected women. Finally, within the German Consortium of Hereditary Breast and Ovarian Cancer, a working group on prophylactic mastectomy was initiated in 2010, together with representatives of gynecologic oncologists, human geneticists, oncologic and reconstructive surgeons, and representatives of health insurances, to generate a consensus paper and guidelines on the best clinical practice of counseling, indication, quality control, and cost refunding for prophylactic mastectomy.

\section{References}

1 Easton DF, Bishop DT, Ford D, Crockford GP: Genetic linkage analysis in familial breast and ovarian cancer: results from 214 families. The Breast Cancer Linkage Consortium. Am J Hum Genet 1993;52:678-701.

$\checkmark 2$ Meindl A, Ditsch N, Kast K, Rhiem K, Schmutzler RK: Hereditary breast and ovarian cancer: new genes, new treatments, new concepts. Dtsch Arztebl Int 2011;108:323-330.

3 Sigal BM, Munoz DF, Kurian AW, Plevritis SK: A simulation model to predict the impact of prophylactic surgery and screening on the life expectancy of BRCA1 and BRCA2 mutation carriers. Cancer Epidemiol Biomarkers Prev 2012;21:1066-1077.

4 Lostumbo L, Carbine NE, Wallace J: Prophylactic mastectomy for the prevention of breast cancer. Cochrane Database Syst Rev 2010;(11):CD002748.

5 Frost MH, Schaid DJ, Sellers TA, Slezak JM, Arnold PG, Woods JE, Petty PM, Johnson JL, Sitta DL, McDonnell SK, Rummans TA, Jenkins RB, Sloan JA, Hartmann LC: Long-term satisfaction and psychological and social function following bilateral prophylactic mastectomy. JAMA 2000;284:319-324.

6 Frost MH, Hoskin TL, Hartmann LC, Degnim AC, Johnson JL, Boughey JC: Contralateral prophylactic mastectomy: long-term consistency of satisfaction and adverse effects and the significance of informed decision-making, quality of life, and personality traits. Ann Surg Oncol 2011;18:3110-3116.

7 Metcalfe KA, Birenbaum-Carmeli D, Lubinski J, Gronwald J, Lynch H, Moller P, Ghadirian P, Foulkes WD, Klijn J, Friedman E, Kim-Sing C, Ainsworth P, Rosen B, Domchek S, Wagner T, Tung N, Manoukian S, Couch F, Sun P, Narod SA; Hereditary Breast Cancer Clinical Study Group International variation in rates of uptake of preventive options in BRCA1 and BRCA2 mutation carriers. Int J Cancer 2008;122:2017-2022.

8 Skytte AB, Gerdes AM, Andersen MK, Sunde L, Brøndum-Nielsen K, Waldstrøm M, Kølvraa S, Crüger D: Risk-reducing mastectomy and salpingooophorectomy in unaffected BRCA mutation carriers: uptake and timing. Clin Genet 2010;77:342-349.

$\checkmark$ Metcalfe KA, Lubinski J, Ghadirian P, Lynch H, Kim-Sing C, Friedman E, Foulkes WD, Domchek S, Ainsworth P, Isaacs C, Tung N, Gronwald J, Cummings S, Wagner T, Manoukian S, Møller P, Weitzel J, Sun P, Narod SA; Hereditary Breast Cancer Clinical Study Group: Predictors of contralateral prophylactic mastectomy in women with a BRCA1 or BRCA2 mutation: the Hereditary Breast Cancer Clinical Study Group. J Clin Oncol 2008;26:1093-1097.

10 Beattie MS, Crawford B, Lin F, Vittinghoff E, Ziegler J: Uptake, time course, and predictors of risk-reducing surgeries in BRCA carriers. Genet Test Mol Biomarkers 2009;13:51-56.

11 Kirova YM, Savignoni A, Sigal-Zafrani B, de La Rochefordiere A, Salmon RJ, This P, Asselain B, Stoppa-Lyonnet D, Fourquet A: Is the breast-conserving treatment with radiotherapy appropriate in BRCA1/2 mutation carriers? Longterm results and review of the literature. Breast Cancer Res Treat 2010;120:119-126.

12 Haffty BG, Harrold E, Khan AJ, Pathare P, Smith TE, Turner BC, Glazer PM, Ward B, Carter D, Matloff E, Bale AE, Alvarez-Franco M: Outcome of conservatively managed earlyonset breast cancer by BRCA1/2 status. Lancet 2002;359:1471-1477.

13 Garcia-Etienne CA, Barile M, Gentilini OD, Botteri E, Rotmensz N, Sagona A, Farante G, Galimberti V, Luini A, Veronesi P, Bonanni B: Breast-conserving surgery in BRCA1/2 mutation carriers: are we approaching an answer? Ann Surg Oncol 2009;16:3380-3387.

14 Graeser MK, Engel C, Rhiem K, Gadzicki D, Bick U, Kast K, Froster UG, Schlehe B, Bechtold A, Arnold N, Preisler-Adams S, NestleKraemling C, Zaino M, Loeffler M, Kiechle M, Meindl A, Varga D, Schmutzler RK: Contralateral breast cancer risk in BRCA1 and BRCA2 mutation carriers. J Clin Oncol 2009;27:5887-5892.

15 Boughey JC, Hoskin TL, Degnim AC, Sellers TA, Johnson JL, Kasner MJ, Hartmann LC, Frost MH: Contralateral prophylactic mastectomy is associated with a survival advantage in high-risk women with a personal history of breast cancer. Ann Surg Oncol 2010;17:2702-2709.

16 Imyanitov EN, Moiseyenko VM: Drug therapy for hereditary cancers. Hered Cancer Clin Pract 2011;9:5.

17 Gerber B, Krause A, Dieterich M, Kundt G, Reimer T: The oncological safety of skin sparing mastectomy with conservation of the nipple-areola complex and autologous reconstruction: an extended follow-up study. Ann Surg 2009;249:461-468

18 Tokin C, Weiss A, Wang-Rodriguez J, Blair SL: Oncologic safety of skin-sparing and nipple-sparing mastectomy: a discussion and review of the literature. Int J Surg Oncol 2012;2012:921821.

19 Peled AW, Foster RD, Stover AC, Itakura K, Ewing CA, Alvarado M, Hwang ES, Esserman LJ: Outcomes after total skin-sparing mastectomy and immediate reconstruction in 657 breasts. Ann Surg Oncol 2012;19:3402-3409.

20 Reynolds C, Davidson JA, Lindor NM, Glazebrook KN, Jakub JW, Degnim AC, Sandhu NP, Walsh MF, Hartmann LC, Boughey JC: Prophylactic and therapeutic mastectomy in BRCA mutation carriers: can the nipple be preserved? Ann Surg Oncol 2011;18:3102-3109.

21 Ananthakrishnan P, Feldman S: Nipple-sparing mastectomy: indications, oncologic safety. Minerva Chir 2012;67:257-270.

-22 Arver B, Isaksson K, Atterhem H, Baan A, Bergkvist L, Brandberg $\mathrm{Y}$, Ehrencrona $\mathrm{H}$, Emanuelsson M, Hellborg H, Henriksson K, Karlsson P, Loman N, Lundberg J, Ringberg A, Askmalm MS, Wickman M, Sandelin K: Bilateral prophylactic mastectomy in Swedish women at high risk of breast cancer: a national survey. Ann Surg 2011;253:1147-1154.
23 Unukovych D, Sandelin K, Wickman M, Arver B, Johansson H, Brandberg Y, Liljegren A: Breast reconstruction in patients with personal and family history of breast cancer undergoing contralateral prophylactic mastectomy, a 10-year experience. Acta Oncol 2012;51:934-941.

24 Gurunluoglu R, Gurunluoglu A, Williams SA, Tebockhorst S: Current trends in breast reconstruction: Survey of American Society of Plastic Surgeons 2010. Ann Plast Surg 2011;Aug 22 [Epub ahead of print].

25 Dieterich M, Dieterich H, Timme S, Reimer T, Gerber B, Stubert J: Using a titanium-coated polypropylene mesh (TiLOOP $\left.{ }^{\circledR}\right)$ Bra) for implant-based breast reconstruction: case report and histological analysis. Arch Gynecol Obstet 2012;286:273-276.

26 Ho G, Nguyen TJ, Shahabi A, Hwang BH, Chan LS, Wong AK: A systematic review and meta-analysis of complications associated with acellular dermal matrix-assisted breast reconstruction. Ann Plast Surg 2012;68:346-356.

27 Kim JY, Davila AA, Persing S, Connor CM, Jovanovic B, Khan SA, Fine N, Rawlani V: A meta-analysis of human acellular dermis and submuscular tissue expander breast reconstruction. Plast Reconstr Surg 2012;129:28-41.

28 Chun YS, Sinha I, Turko A, Yueh JH, Lipsitz S, Pribaz JJ, Lee BT: Comparison of morbidity, functional outcome, and satisfaction following bilateral TRAM versus bilateral DIEP flap breast reconstruction. Plast Reconstr Surg 2010;126:1133-1141.

29 Momoh AO, Colakoglu S, Westvik TS, Curtis MS, Yueh JH, de Blacam C, Tobias AM, Lee BT: Analysis of complications and patient satisfaction in pedicled transverse rectus abdominis myocutaneous and deep inferior epigastric perforator flap breast reconstruction. Ann Plast Surg 2012;69:1923.

30 Gill PS, Hunt JP, Guerra AB, Dellacroce FJ, Sullivan SK, Boraski J, Metzinger SE, Dupin CL, Allen RJ: A 10-year retrospective review of 758 DIEP flaps for breast reconstruction. Plast Reconstr Surg 2004;113:1153-1160.

31 Drazan L, Vesely J, Hyza P, Castagnetti F, Stupka I, Justan I, Novak P, Monni N: Bilateral breast reconstruction with DIEP flaps: 4 years' experience. N J Plast Reconstr Aesthet Surg 2008; 61:1309-1315.

-32 Guerra AB, Metzinger SE, Bidros RS, Rizzuto RP, Gill PS, Nguyen AH, Dupin CL, Allen RJ Bilateral breast reconstruction with the deep inferior epigastric perforator (DIEP) flap: an experience with 280 flaps. Ann Plast Surg 2004:52:246-252.

33 Granzow JW, Levine JL, Chiu ES, Allen RJ: Breast reconstruction with gluteal artery perforator flaps. J Plast Reconstr Aesthet Surg 2006;59:614621.

34 Dieterich $\mathrm{M}$, Dieterich $\mathrm{H}$, Nestle-Krämling C, Gerber B: [Certification of Breast Surgeons in Germany - AWO-gyn Curriculum in an International Comparison]. GebFra 2009;11:987-992. 